Samir Ćoragić, prof.

\title{
KRATKE LINGVISTIČKE POVEZNICE JEZIKA I RELIGIJE
}

SAŽETAK

Prožimanje religijskoga u jeziku i jezičkoga u religiji je sveprisutno. $O$ tome se dosada i nije toliko pisalo iz ideoloških razloga. U ovom radu se otvaraju moguća pitanja istraživanja toga problema: odnosa jezika i religije (gledano sa sociolingvističkog aspekta), utjecaju religije u čuvanju i kultiviranju bosanskoga jezika, odnosno jezika kao instrumenta religije, religijskom funkcionalnom stilu, te jeziku $i$ religiji kao značajnim segmentima građenja nacionalnog identiteta jednoga naroda. Da se religija ne može posmatrati kao čisti ekstralingvistički faktor, dokaz je i ovaj rad.

Ključne riječi: bosanski jezik, identitet, islam, jezik, nacija, religija, religijski funkcionalni stil.

\section{Uvod}

O odnosu jezika i religije na širem južnoslavenskom prostoru (prostoru srednjejužnoslavenskoga dijasistema) je malo pisano. Razloge možemo tražiti u prijašnjem društveno-pravnome poretku, zasnovanome na marksističkom učenju koje je u znatnoj mjeri religijskom negiralo dokazani značaj $u$ izgrađivanju vlastite samosvijesti i kulture, odnosno razlozi su i u poimanju, te indirektnome negiranju religije od sekularističkih društava - religija je privatna stvar. Obično se o odnosu jezika i religije govorilo kroz ideologiju, gdje je ideologija često puta bila sinonim za religiju. Naime, samo su religijske intencije bojane kao ideološke, a sve ostale su bile napredne $i$ svrsishodne. Trend zapećka ovoga problema nastavio se i u današnje vrijeme. Istina, javljaju se izvjesne naznake bavljenja religijskim u određenim jezičkim korpusima, dakako površinski. Koliko je poznato još nismo dobili cjelovitiju analizu i sintezu o ovome problemu na našem prostoru.

U odnosu na južnoslavenski prostor evropska i američka lingvistika znatno je više posvetila pažnje religijskome u jeziku i odnosu jezika i religije. Tako je javna tajna da se u svijetu govori npr. 
o religijskom funkcionalnom stilu, religijskom žargonu, religijskom idiomu, religijskim sociolektima itd. Ipak uz sve to, ni tu lingvistika nije posvetila dužnu pažnju religijskoj komponenti u jeziku. Razlozi za to su posve jasni i nama poprilično slični. Srednjovjekovna skolastika, te Crkva kao najbogatija institucija i zemljoposjednik, a onda i sekularističko gledanje na religiju, gradili su kod zapadnoga čovjeka popriličan prezir prema svemu religijskom. Upravo zbog toga ni na tome prostoru, čini se, nema kompleksnije analitičke studije o ovome problemu.

Cilj nam nije dokazivati religijsko naslijeđe u jeziku, jer se ono ne mora dokazivati - ono je tu odvajkada. Cilj nam je ukazati na glavne pravce istraživanja kojima bi se trebalo baviti u nekom budućem istraživanju. Koristeći naučnu metodologiju i nikako drugačije, uzimajući u obzir sve lingvističke fakte. Danas se u našem društvu religija i religijsko pokušava ograničiti na religijske institucije, što je s naučnog aspekta interdisciplinarnosti nedopustivo. Upravo je jezik argument za to, čije religijske slojeve nalazimo u svim vrstama diskursa.

\section{Određivanja pojmova jezik i religija}

Određivati pojmove koji su širokog značenja za svakoga je istraživača dakako teško i uvijek ga može dovesti u sukob s različitim tumačenjima istoga. Od toga ne treba bježati, već treba ograničiti određenja na razinu tematike naučnog bavljenja i naučnog gledanja s određene tačke gledišta. Upravo tako ćemo i mi objašnjavati i određivati pojmove jezika i religije.

U savremenoj lingvistici određenje pojma jezik je različito i višestruko. Ukratko, najfrekventnije je mišljenje strukturalističke lingvistike, utemeljeno na De Sosirovskim dihotomijama i teoretskim postavkama, da je jezik sistem znakova i da kao takav pripada porodici semiologije zajedno $\mathrm{s}$ ostalim neverbalnim sistemima sporazumijevanja. ${ }^{1}$ Svakako, jezik kao najsavršeniji oblik komunikacije, ima primarno mjesto u semiologijskome sistemu. On je najznačajniji i najsloženiji sistem sporazumijevanja. Istraživači kao npr. Roland Bart, semiotičar po naučnome određenju, podređuju

\footnotetext{
${ }^{1}$ F. De Sosir, Opšta lingvistika, Nolit, Beograd, 1977.(2) str. 75.
} 
semiotiku jeziku čime se ukazuje sa sav značaj i vrijednost ovoga sistema komunikacije.

S druge strane, generativna gramatika značajno temeljeći svoje učenje na psihologiji (posebno kognitivnoj) i vraćanjem na logičku gramatiku Port Royala, jezik određuje kao ono bitno, što čovjeka odlikuje i razlikuje od životinje. Jezik je specifična ljudska imovina i proizvod. $^{2}$

Religija, za razliku od jezika, ima brojne sinonime: vjera, svjetonazor, sakralnost, vjeroispovijest i sl. Zanimljivo je da termin religija doslovno znači zavisnost, ovisnost, privrženost. Dakle, religija bi bila nasušna potreba, nasušna ovisnost, što se može kazati i za jezik. Svaki od ovih sinonima ima svoje mjesto u diskursu, zavisno od društvene grupe koja koristi spomenute sinonime. Tako će npr. vjerski službenici govoriti gotovo uvijek vjera, teolozi religija, novinari vjeroispovijest, filozofi svjetonazor itd. Mi ćemo se opredijeliti za termin religija, jer je on po našem shvatanju najpodesniji ovoj našoj problematici.

\section{Religijsko poimanje jezika}

Najranija čovjekova interesiranja za jezik bila su u učenju čarobnih riječi kojima se nastojalo zaštiti porodicu od mračnih sila, dozvati dobrog duha, izliječiti se od bolesti itd. Dakle, početak čovjekovog interesiranja za jezik veže se za kult i obredoslovlje. Prilika za razvoj i usavršavanje jezika desila se objavljivanjem svetih knjiga Božijim poslanicima, kada jezik poprima najznačajniju funkciju u širenju Božije riječi, a preko toga i doprinosi razvoju pismenosti (sjetimo se samo religijsko-jezičkoga djelovanja solunske braće, Ćirila i Metodija, na opismenjavanju barbarskih Slavena, stvaranju glagoljice kao prvog slavenskog pisma i staroslavenskog kao prvog književnog jezika). Sve objavljene svete knjige imale su neopisivu ulogu u razvoju pismenosti i izgradnji kulture svih naroda. Jezika postaje sakraliziran i instrument spoznaje Boga. Bez jezika je nemoguće pozivati u vjeru, pozivati na Pravi put. To je i razlog da se

\footnotetext{
${ }^{2}$ Kolika je važnost jezika vidi se i po tome što oblik jezik nema sinonima, ni pravog ni nepravog u većini svjetskih jezika, izuzmemo li potpune sinonime koji nastaju prevođenjem: lang = jezik i sl.
} 
jeziku u religiji i religiji u jeziku posveti dostojanstvena pažnja. Većina svjetskih mislilaca svih naučnih i umjetničkih profilacija dotiču se jezika i religije, njegovog porijekla, upotrebe, raslojavanja, kultiviranja itd.

Kada je riječ o porijeklu jezika, religija na njega gleda kao na Božansko davanje. Pripisuje mu se Božansko porijeklo i stavlja ga se na sami početak čovječjega stvaranja. On se objašnjava kao i sam atribut Boga, koji je zajedno s dušom udahnut u ljudsko tijelo. O tome se kaže u Bibliji:

I reče Jahve, Bog: 'Nije dobro da čovjek bude sam (...) 'Tada Jahve, Bog načini od zemlje sve životinje u polju i sve ptice, i privede ih čovjeku da vidi kako će koju nazvati, pa kako koje čovjek stvorenje prozove, da mu tako bude ime. Čovjek nadjene ime svoj stoci, svim pticama u zraku i životinjama u polju. ${ }^{\beta}$

Ili u Kur'anu:

I pouči On Adema nazivima svih stvari, a onda ih predoči melekima i reče:'Kažite mi nazive njihove ako istinu govorite!' 'Hvaljen nek' si!', rekoše oni. 'Mi znamo samo ono čemu si nas Ti poučio (...)'. ' O Ademe', reče On, 'kaži im ti nazive njihove! ${ }^{A}$

Svrha svakog jezika je ostvarenje komunikacije. Jezička djelatnost se ostvaruje preko unaprijed usvojenog koda od pošiljaoca (samog Boga ili njegovog halife) do primaoca (vjernika).

Jezik je u samome čovjeku. Upravo početak Evanđelja po Ivanu govori u prilog tome: U početku bijaše Riječ/ i Riječ bijaše uz Boga/ $i$ Riječ bijaše Bog. ${ }^{5}$

Jezik je najposrednija veza između Boga i čovjeka. Da bi širio Svoju misiju na čovjeka, Bog ga je morao opremiti odgovarajućom aparaturom - jezikom. Kada mu je udahnuo dio Sebe $(r u h)$, udahnuo mu je i jezik.

Kao što se svako dijete rađa u religiji, tako se i jezik rađa $u$ djetetu. Dijete će progovoriti na onome jeziku u zavisnosti od svog

\footnotetext{
${ }^{3}$ Biblija, Stvaranje svijeta 18,19,20,21, Knjiga Postanka, Zagreb, 1969.

${ }^{4}$ Kur'an, Krava, Medina Munevvera, 1996., str. 31.

${ }^{5}$ Biblija, Novi Zavjet, Evanđelje po Ivanu, Dom štampe Zenica, Sarajevo, 2001., str. 158.
} 
društvenog, pa i religijskog okruženja. Ovo je argument učenju o jeziku kao društvenoj kategoriji. Jezik se može realizirati samo $u$ društvu i nikako više. Ukoliko ne postoje uvjeti za to, jezik je osuđen na propast, uništenje. Jezik je bitna ljudska diferencijacija u odnosu na životinje:

Za životinje koje ne govore i nemaju jezik, mada komuniciraju, svijet ne postoji, postoje samo određene stvari-logika vrste. ${ }^{6}$

Glotonijska pitanja (pitanja porijekla jezika) su bila aktuelna posebno u XIX stoljeću, kada su izdeklamirane različite nativističke, biologističke i darvinističke teorije koje i danas ne prestaju zaokupljati lingviste. Nijedna od tih teorija nije odgovorila na fenomen jezika. Nijedna se ne može osporiti, sve imaju svoje pokriće i mogućnost vjerovatnoće, no sve zajedno opet ne mogu objasniti porijeklo i nastanak jezika.

\section{Religijski funkcionalni stil}

U općeprihvaćenoj podjeli, funkcionalnog raslojavanja jezika, na pet funkcionalnih stilova (književnoumjetnički, naučni, administrativno-pravni, novinarsko-publicistički i kolokvijalni) religijski stil nije našao svoje zasebno mjesto, kao šesti funkcionalni stil. Dakako, uvijek se za njega znalo kao što se zna i za šesto čulo. Zanemarivan je i najčešće pripajan književnoumjetničkom stilu sa kojim zbilja ima najviše sličnosti, ali i očigledne razlike, pošto religijski stil u sebi sadrži od svakoga stila pomalo. U isto je vrijeme književnoumjetnički a donekle naučni (propovjednici se obraćaju vjernicima koristeći naučne spoznaje i često puta naučni diskurs, koriste naučnu metodologiju); nekad je književnoumjetnički a dijelom i administrativno-pravni (propovjednici se služe pravnim diskursom u objašnjavanju propisa vjere); najviše je kolokvijalni (kada propovjednici iznose adekvatne životne primjere da potkrijepe svoje teze.

Ovakvo gledanje na funkcionalnu diferencijaciju jezika, smatra se uskim i nenaučnim (religijskom funkcionalnom stilu se uklanja

${ }^{6}$ M. Filipović, Jezik u našem mišljenju $i$ naše mišljenje jezika, Simpozij o bosanskom jeziku, Zbornik radova, Institut za jezik u Sarajevu, Sarajevo, 1999., str. 20 . 
zasluženo mjesto u sistemu funkcionalnih stilova). Spomenuto shvatanje se ne može braniti naučnim argumentima, nego samo argumentima religiji pripisane ideologije, koje u religiji, istina, i ima. No, to nije razlog da religijski funkcionalni stil ne zauzme svoje mjesto ravnopravno uz ostale stilove. Ovaj je stil najstariji od svih. Rastao je uz čovjeka, te bi se slobodno mogli tvrditi, ako imamo u vidu povijest ljudske pismenosti, da je ovaj stil sa svojim vrstama utjecao i na samu funkcionalnu diferencijaciju jezika.

Ovako velik značaj religijskog funkcionalnog stila uočila je N. B. Mečkovskaja:

Sakralni stil obuhvata sferu usmene $i$ pismene religijske kompetencije, tako da je žanrovski veoma raznorodan - počev od svetih knjiga različitih religija pa do jezika i stila izvođenja religijskih obreda, molitvi, obraćanja vjerskih službenika vjernicima $i$ slično. Upravo ova stroga diferencijacija žanrova, tačnije svojevrsna hijerarhija sakralnih tekstova, znatno je utjecala na funkcionalno raslojavanje jezika uopće, kao i na uočavanje specifičnih stilskih svojstava različitih tipova upotrebe jezika uopće.

Osnovni razlozi funkcionalnog raslojavanja jezika potječu iz čovjekovog nastojanja da u različitim sferama svog društvenog života komunicira na najbolji mogući način. Primarni uzroci funkcionalnog raslojavanja leže u ekstralingvističkim faktorima, a svrha im je što jasnija komunikacija.

O tome M. N. Kožina kaže:

Jedan od kriterija, principa podjele (određivanja i klasifikacije funkcionalnih stilova) jeste pripadnost govornog sistema navedenom kompleksu (jedinstvu) ekstralingvističkih baznih faktora, koji $i$ uslovljavaju specifičnost govornog sistema stila, odnosno, u pravom smislu, sam stil. ${ }^{8}$

Koliko god da su sjajni ruski lingvisti i stilističari dokazivali postojanje religijskog funkcionalnog stila, ipak se na njihove tvrdnje gledalo poprilično skeptično. Vjerovatno zbog toga što religijski

\footnotetext{
${ }^{7}$ M. Katnić-Bakaršić, Stilistika, Ljiljan, Sarajevo, 2001., str. 70.

8 B. Tošović, Funkcionalni stilovi; Institut für Slawistik der Karl-FranzensUniversitat Graz, Graz, 2002., str. 53.
} 
funkcionalni stil nisu jasno izdvojili u odnosu na druge. Svakako najznačajniji pojedinac za priznavanje religijskog funkcionalnog stila, jeste engleski lingvist Najer koji je 1981. godine po prvi put izdvojio ovaj stil kao zaseban i nazvao ga religijskim:

Religiozni stil engleskog jezika također je, očigledno, vrsta engleskog književnog jezika koja se koristi u specifičnoj oblasti komunikacije, koja ima jasnu (funkcionalnu) usmjerenost na prodiranje ili ispoljavanje religiozne svijesti posredstvom intenzivnog emocionalnog djelovanja ili izražavanja volje $i$ koja se odlikuje određenim sistemom jezičkih sredstava. Po svoj prilici, za savremeno stanje engleskog jezika i odgovarajućeg društva ova stilistička vrsta nipošto nije postala relikt, jer je religiozna propaganda, bez obzira na intenzivan razvoj sredstava svjetovne buržoaske propagande, na širenju prosvjete, naučnih saznanja i progresivnih ideja, očigledno, ne namjerava da još prepusti svoje pozicije."

Primjećuje se da su u religioznom funkcionalnom stilu stilska sredstva bogata i da imaju didaktičo-apelativnu funkciju, jer djeluju na vjernike kao jedna dogmatska poruka koja iza sebe ima nedodirljiv autoritet. Osnovna svrha jezika je, po religijskome učenju, očuvanje izvornosti svetih knjiga i tekstova. Kako je sama Riječ Bog, tako se preko jezika kroz svete knjige, Bog obraća ljudima. ${ }^{10}$

\section{Bosanski jezik i islam}

Prisustvo islamske komponente $\mathrm{u}$ bosanskome jeziku je, svakako, veliko. Razlozi tome leže u dugogodišnjoj osmanskoj vladavini u $\mathrm{BiH}$, gdje je afrimiran i kultiviran islam kao religija kulture i gospodstva, preko kojega su islamski utjecaji obogatili slavensku jezičku bazu srednjovjekovnih dobrih Bošnjana. Upravo se na primjeru bosanskoga jezika pokazuje kako se religija ne može posmatrati samo kao ekstralingvistički faktor u jeziku.

\footnotetext{
${ }^{9}$ Ibid., str. 55 .

${ }^{10} \mathrm{O}$ religijiskom funkcionalnom stilu: A. Kozlica, Religijski funkcionalni stil (Analiza funkcionalnog stila), Diplomski rad, Pedagoški fakultet, Bihać, 2004.
} 
Širenjem islama ${ }^{11}$ prihvataju se orijentalni jezici, ali nikad $\mathrm{u}$ razgovornoj sferi. Orijentalni jezici ostat će privilegija pismenijih i uglednijih građana. O tome da orijentalni jezici nikad nisu bili autohtona i upotrebna baština Bošnjaka govori upravo činjenica da su od orijentalnih jezika Bošnjaci uzeli samo arapsko pismo i ništa više. Poznati su i drugi narodi koji su došli pod osmansko-islamski utjecaj da su imali istu praksu. Dakle, ne može se spočitavati Bošnjacima da su Turci $^{12}$, pošto je povijesno utvrđeno da se nikada u kolokvijalnoj sferi nisu služili turskim jezikom. Drugo, da su zbilja Turci danas bi govorili turskim, a ne bosanskim jezikom. Pitanje grafije je sasvim nešto drugo. Istina je da su Bošnjaci svojim pisanjem obogatili orijentalnu nauku i kulturu i da su se dokazali na svim naučnim i umjetničkim poljima u najsjajnije vrijeme Osmanskog carstva.

O samome širenju orijentalnih jezika na našem prostoru govori Dževad Jahić: Zajedno sa takvim načinom širenja islama, u Bosni ide $i$ proces jezičkog mijenjanja, pojave jezičkih inovacija primanih iz turskog $i$ arapskog jezika. Iz turskog jezika se u (vremenom novoštkovaziranu) zapadnu štokavštinu primaju riječi novih značenja, tzv. turcizmi. To je najznačajniji jezički sloj koji prati proces islamizacije... $^{13}$

Zanimljivo je da od tri orijentalna jezika najveći utjecaj na slavensku bazu bosanskog jezika ima upravo arapski jezik - kao jezik religije, a posebno jezik Kur'ana koji postaje motivacioni faktor otvaranja škola za izučavanje Kur'ana (mekteba i medresa). Utjecaj arapskog jezika u savremenom bosanskom jeziku i na dijalekatskome planu možemo pratiti na svim jezičkim razinama:

\footnotetext{
${ }^{11} \mathrm{U}$ nauci je gotovo općeprihvaćen izraz islamizacija kada se govori o prihvatanju islama nemuslimana na Balkanu. Taj termin ne odgovara pravoj slici stanja. Naime, poznato je islamsko načelo kako u vjeru nema prisile, pa tako ni izvedenica islamizacija koji u sebi sadrži nasilnu boju (slično deretizacija, likvidacija, majorizacija i sl.) nije prikladna za nauku. Bolje je kazati širenje islama. Uostalom, savremeni historičari više ne rabe ovaj izraz, jer ga smatraju pogrešnim.

${ }^{12} \mathrm{Ni}$ naziv Turci naučno nije ispravan. U historiografiji se uvijek govori Osmani (Osmanlije), pošto je to bio zvanični naziv Carstva, a i sami su se tako nazivali. Turci su naziv naroda koji se, povijesno gledano, raselio i razdijelio na razne druge narode, uzevši drugačija imena, kao što od Slavena svoje porijeklo vuče većina južnoslavenskih naroda.

${ }^{13}$ Dž. Jahić, Bosanski jezik u 100 pitanja i 100 odgovora, Trilogija o bosanskom jeziku, Knjiga 2., Izdavačko preduzeće ZE-COMPANY, Zenica, 2000., str. 21.
} 


\section{1. na fonetsko-fonološkoj razini:}

- Dosljedno čuvanje i upotreba glasa h u svim pozicijama u riječi pod utjecajem fonologije arapskog jezika koji za taj glas ima 3 foneme $\mathrm{h}$. Naime, u lingvistici se vodila rasprava oko toga zašto Bošnjaci čuvaju glas h? Većina lingvista je tvrdnje kako je arapski jezik pomogao da se taj glas očuva baš kod Bošnjaka, pošto je XV stoljeće vrijeme kada se taj glas počinje polahko gubiti, prvo na kraju riječi. Svi jezički zakoni su uglavnom završeni i zatvoreni u XV stoljeću;

- Geminacije kao jezički i artikulacijski gotovo identične arapskome tešdidu (udvostručenju glasa), radi jezičke ekonomije. I ovdje je, po našem mišljenu presudnu ulogu odigralo učenje arapskog jezika. Naime, gubljenje suglasnika u riječima je uzrokovalo pojavu geminacije, pošto je ostala djelimična artikulacijska praznina nakon ispadanja suglasnika (gladna - glanna, padnula - pannula i sl). Upravo će arapski tešdid odigrati veliku ulogu u konzerviranju i očuvanju geminata na dijalekatskoj bazi.

2. Posebno na morfonološkoj, morfološkoj i leksičkoj bazi:

- Velika leksika religijske diferencijacije (ibadetiti, zikriti, doviti, halaliti, haramiti itd). Na orijentalnu osnovu dodaju se domaći slavenski nastavci za gradnju glagolskih oblika i obrnuto (dodavanje sufiksa orijentalnog porijekla na domaću slavensku osnovu);

- Imena i prezimena orijentalnog porijekla sa specifičnim arapskim mehkim k koje se u bosanskom jeziku translituje kao ć (Ćazim, Ćamil, Ćufurović, Ćoralić itd). Evlija Čelebija putujući kroz Bosnu bilježi, za njega zanimljivost, kako stanovnici krate lična imena, tipa Meho (Mehmed), Sulejman (Suljo), Muhamed (Mujo) itd;

- Arapsko grleno $a(a j n)$ se translituje kao o u bosanskom jeziku, opet u ličnim imenima (Omer, Osman i sl);

- Zanimljivo je i preuzimanje srodničke nominacije iz arapskog jezika u imenovanju osobe sinom ili kćerkom nekoga. U bosanskom jeziku (Hasan Ibrahimov, Sulejman Omerov, Fata Mujagina i sl). U arapskom jeziku Zeid ibn Sabit (Zeid sin Sabitov), Fatima bintu Muhamed (Fatima kćerka Muhameda). 
3. Na leksičko-semantičkoj razini velika upotreba sinonima, antonima i frazema (odužio k'o teraviju, gladan k'o hadžija, maslo za Ramazana itd).

Sve ove pojave koje smo naveli, a kojih ima znatno više, ukazuju na to da je nemoguće posmatrati bosanski jezik bez religijske komponente koja u našem jeziku više nema status isključivo religiozne, nego se ona prenijela i na svjetovnu upotrebu. Upravo zahvaljujući religiji stvarao se duhovni jezički kolorit koji je danas glavna osobina pitkosti bosanskog jezika. Tako će kazati Dž. Latić:

$U$ 'duši' toga jezika, od XV vijeka na ovamo, leži islam sa svojim svjetonazorom, kulturom i civilizacijom. ${ }^{14}$

Najveću potvrdu naših tvrdnji nalazimo u književnim djelima bošnjačkih pisaca kako iz epohe književnog stvaranja na orijentalnim jezicima $\mathrm{i}$ alhamijado stvaralaštvu, tako $\mathrm{i}$ naše savremene bh. književnosti (Meša Selimović, Ćamil Sijarić, Abdulah Sidran, Nedžad Ibrišimović itd.), gdje je upravo bosanski jezik, sa svojom religijskom komponentom, ono što ih potvrđuje i daje im bosanski duhovni pečat. Prevođenjem tih književnih djela na strane jezike gubi se na njihovoj književnoumjetničkoj vrijednosti upravo zbog religijske komponente u bosanskom jeziku. Tako je nemoguće npr. profesiju Ahmeda Nurudina (derviš) prevoditi kao isposnik, što je nažalost čest slučaj i od samih bošnjačkih prevodilaca, zaboravljajući da je književnoumjetničko djelo semantički autonomna kategorija.

\section{Jezik i religija kao komponente nacionalnog identiteta}

Jezik i religija zajedno sa ostalim duhovnim i kulturološkim komponentama grade identitet jednog naroda. To je ono što ih čini specifičnim i osobenim u odnosu na druge. Kada se govori o nacionalnome identitetu, jezik i religija, pored nacije i naroda su odmah na drugom mjestu. Jezik se gotovo uvijek veže uz naciju, a nacija opet posredno preko jezika sa religijom. Prilikom popisa stanovništva nezaobilazne stavke su pitanja o religiji i o jeziku. Nije tajna da se jeziku posvećivala tolika pažnja da se on često puta, nažalost, i instrumentalizirao. Koliko je jako društvo koje kultivira

${ }^{14}$ Dž. Latić, Kako izbjeći nacionalizam u jeziku, Simpozij o bosanskom jeziku, Zbornik radova, Institut za jezik u Sarajevu, Sarajevo, 1999., str. 44. 
određeni jezik, toliko će biti jaka i sama dominacija toga jezika u odnosu na druge, te preko jezika upoznavanje drugih s religijom dominantnog društva. Francuski jezik kao lingua franca u XIX stoljeću, te engleski jezik kao top-language u XX stoljeću.

Sjetimo se kako se nekad u Bosni razlika među narodima određivala isključivo na osnovu pripadnosti religiji. Tako se govorilo o Bošnjacima-muslimanima, Bošnjacima-pravoslavcima i Bošnjacima-katolicima. U tom smislu ni naziv jezika nije bio sporan, sve do nacionalnog buđenja Srba i Hrvata, potpomognutog snažnom ideološkom agitacijom iz država matica, kada i naziv jezika postaje predmet sporenja.

Danas se u lingvističkom svijetu velika pažnja pridaje očuvanju jezika koji su ugroženi i kojima prijeti jezička smrt. U tom smislu su donesene brojne lingvističke deklaracije o pravima svakog naroda na vlastiti jezik u nominaciji, upotrebi i kultivaciji jezika. Jezik je uz religiju ono na što je svaki čovjek ponosan, ali i ono je u današnjem društvu najsklonije kritici, opovrgavanju i uskraćivanju. Tako je na bh. prostoru bezbroj diletantskih jezikoslovaca i religijskih znalaca koji pokušavaju iskoristiti i jezik i religiju za vlastite utilitarističke ciljeve.

\section{Zaključci}

1. Prožimanje religije kroz jezik i jezika kroz religiju je veliko i može se pratiti na svim jezičkim razinama.

2. Jezik je instrument religije.

3. Bez jezika nema religije kao što ni religije nema bez jezika.

4. Jezik svoj razvoj duguje religiji, koja ga je i afirmirala, bar u starijim vremenima preko kulta, vjerovanja i obreda, odnosno izučavanjima svetih knjiga i potrebama za njihovim pravilnim iščitavanjem.

5. Funkcionalnim raslojavanjem jezika nastao je religijski funkcionalni stil koji ravnopravno stoji uz ostale funkcionalne stilove.

6. Religijski funkcionalni stil obiluje brojnim stilskim sredstvima i tropima kao svojevrstan način kićenja jezika. 
7. Od svih orijentalnih jezika najveći je utjecaj na bosanski jezik imao arapski jezik, kao jezik religije (islama), neposredno ili posredno preko osmansko-turskog jezika.

8. Islamska komponenta u bosanskom jeziku je duša toga jezika.

9. Jezik i religija, uz nacionalnost i kulturu, su temelji nacionalnog identiteta.

\section{Literatura:}

1. Antoš Antica, Osnove lingvističke stilistike, Školska knjiga, Zagreb, 1974.

2. Biblija, Stvarnost, Zagreb, 1969.

3. Biblija, Novi Zavjet, Dom štampe Zenica, Sarajevo, 2001.

4. Cerić Mustafa, Bajramska hutba - poruka, Rijaset Islamske zajednice, Sarajevo, 1996.

5. De Sosir Ferdinand, Opšta lingvistika, Nolit, Beograd, 1977.(2)

6. Hadžiefendić-Parić Remzija, Naš jezik, Sarajevo Publishing, Sarajevo, 2003.

7. Handžić Mehmed, O hutbi, Eseji rasprave članci, Ogledalo, Sarajevo, 1999.

8. Ivić Milka, Pravci u lingvistici, Državna založba Slovenije, Ljubljana, 1970.

9. Jahić Dževad, Bosanski jezik u 100 pitanja $i 100$ odgovora, Trilogija o bosanskom jeziku, Knjiga 2., Izdavačko preduzeće ZE-COMPANY, Zenica, 2000 .

10. Jakobson Roman, Lingvistika i poetika, Nolit, Beograd, 1996.

11. Katnić-Bakaršić, Marina, Stilistika, Ljiljan, Sarajevo, 2001.

12. Kozlica Amra, Religijski funkcionalni stil (Analiza funkcionalnog stila), Diplomski rad, Pedagoški fakultet, Bihać, 2004.

13. Kur'an, Prevod, Besim korkut, Medina Munevvera, 1996.

14. Peco Asim, Ikavskošćakavski govori zapadne Bosne I, Bosansko filološko društvo Sarajevo, Sarajevo, 2007.

15. Radovanović Milorad, Sociolingvistika, Novi Sad, 1976.

16. Simpozij o bosanskom jeziku, Zbornik radova, Institut za jezik Sarajevo, Sarajevo, 1999.

17. Tošović, Branko, Funkcionalni stilovi, Institut für Slawistik der Karl-FranzensUniversität Graz, Grac, 2002. 
SAMIR ĆORAGIĆ, B.A.

BRIEF LINGUISTIC CONNECTIONS OF LANGUAGE AND RELIGION

\section{SUMMARY}

Mutual permeation of religion in language and language in religion is enormous. Not much has been said about it in the previous times primarily due to the ideological reasons.

In this, paper possible research questions of this problem arise, such as: relation of language and religion from a social-linguistic point of view; religious influence on preservation and cultivation of Bosnian language, thus meaning language as an instrument of religion; religious functional linguistic style and religion as an important factor in establishing national identity.

This paper is evidence that religion cannot be viewed as a pure extra- linguistic factor. 


$$
\text { الأستاذ سامر تشوراغيتش }
$$

الارتباطات اللغوية القصيرة بين اللغة والدين

\section{خلاصة البحث}

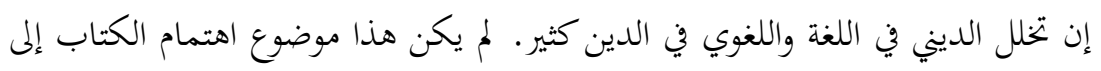
الآن لأسباب أيديولوجية. يعتبر هذا البحث فتح بحال لدراسة هذا الموضوع: العلاقة بين اللغة والدين (إذا نظرنا من الجانب الاجتماعي اللغوي)، تأثير الدين في الحفاظ على اللغة البوسنوية ورعايتها، أو اللغة بوصفها أداة للدين، والكلام حول الأسلوب الديني الفعّال، إضافة إلى اللغة

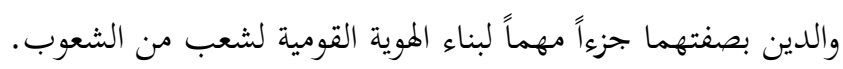

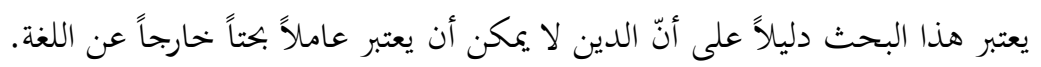

